\title{
The Optimum Dosage of Prilocaine in Periprostatic Nerve Block During Transrectal Ultrasound Guided Prostate Biopsy: A New Approach in Dose Calculation
}

\section{TransrektalUltrason Klavuzluğunda Yapılan ProstatBiyopsisinde Uygulanan Periprostatik Sinir Blokajında Uygun Prilokain Dozu: Doz Hesaplamada Yeni Bir Yaklașım}

\author{
Umut Gönülalan MD1, Murat Koşan MD1, Enis Kervancığlu MD2, Tufan Çiçek MD1, Bülent Öztürk MD1, Hakan Özkardeş MD1 \\ ${ }^{1}$ Bașkent University Faculty of Medicine, Department of Urology, Konya, Turkey \\ 2Ankara Numune Education and Research Hospital, Clinic of Urology, Ankara, Turkey
} \begin{abstract}
Summary
Objective: We aimed to calculate the optimum dose of prilocaine per one $\mathrm{mL}$ prostate volume in periprostatic nerve block (PPNB) during transrectal ultrasound (TRUS) guided prostate biopsy (PBx).

Materials and Methods: We retrospectively evaluated the medical records of 83 patients from whom 12 cores TRUS guided PBx were obtained between years 2011 and 2013. Prostatic sizes were evaluated separately as Size 1 (anterior-posterior on the axial plane), Size 2 (transversal), and Size 3 (cranial-caudal on the sagittal plane) for all patients. The visual analog scores (VAS) of the patients during PBx, prostatic volumes, and prilocaine doses per one $\mathrm{mL}$ prostate were evaluated. The correlation between VAS of patients during PBx and prostatic volume, the prostatic sizes and prilocaine dosage per one $\mathrm{mL}$ prostate was analyzed using Cubic regression test.
\end{abstract}

Results: It was found that VAS scores of patients were significantly positive correlated with prostatic volume, Size 1,2 and $3(p<0.05)$. However, there was a negative significant correlation between VAS and prilocaine dose per one $\mathrm{mL}$ prostate volume $(\mathrm{r}=-0.402, \mathrm{p}<0.01)$. The dose of 0.1 $\mathrm{mL}$ prilocaine infiltration per one $\mathrm{mL}$ prostatic tissue in PPNB was the maximum dose that caused a mild and under annoying pain $(V A S<2)$ in patients according to cubic regression formula.

Conclusion: Prilocaine dosage, prostatic volume and prostatic sizes (especially anterior-posterior and cranial-caudal) significantly affect VAS scores during TRUS guided PBx. The pain in TRUS guided PBx should be controlled with an optimum dose of prilocaine as $0.1 \mathrm{~mL}$ per one $\mathrm{mL}$ of prostatic tissue.

Keywords: Pain, prilocaine, prostate, periprostatic nerve block, transrectal ultrasound
Öz

Amaç: Amacımız transrektal ultrason (TRUS) kılavuzluğunda yapılan prostat biyopsisinde (PB) uygulanan periprostatik sinir blokajında (PPSB) prostat hacmi başına en uygun prilokain dozunun hesaplanmasıdır.

Gereç ve Yöntem: 2011-2013 yılları arasında 12 kor TRUS kılavuzluğunda PB alınan 83 hastanın tıbbi kayıtları geriye dönük incelendi. Prostat boyutu, aksiyel planda antero-posterior (Boyut 1) ve transvers ölçüm (Boyut 2) ve sagittal planda kraniyo-kaudal ölçüm (Boyut 3) kullanılarak hesaplandı. TRUS-PB esnasındaki visual analog skala (VAS), prostat hacimleri ve $1 \mathrm{ml}$ prostat hacmi başına uygulanan prilokain dozu değerlendirildi. Hastaların VAS ile prostat hacimleri, prostat boyutları ve uygulanan prilokain dozları arasındaki korelasyon Cubic regresyon testi ile hesaplandı.

Bulgular: VAS ile prostat boyut 1, 2, 3 ve prostat hacmi arasında anlamlı olarak pozitif korelasyon mevcuttur $(p<0,05)$. Ancak VAS ile $1 \mathrm{ml}$ prostat hacmi başına prilokain dozu arasında anlamlı olarak negatif korelasyon mevcuttur $(r=-0,402, p<0,01)$. Kübik regresyon formülüne göre TRUS kılavuzluğunda PB sırasında hafif ve rahatsız etmeyen ağrı düzeyi $(V A S<2)$ için PPSB sırasında yapılması gereken maksimum prilokain dozu $1 \mathrm{ml}$ prostat hacmi başına $0,1 \mathrm{ml}$ prilokain infiltrasyonudur.

Sonuç: TRUS kılavuzluğunda PB sırasında saptanan VAS, prilokain dozu, prostat hacmi ve özellikle antero-prosterior ve kraniyo-kaudal prostat boyutlarından anlamlı olarak etkilenmektedir. TURS kılavuzluğunda PB esnasındaki ağrı $1 \mathrm{ml}$ prostat dokusu başına 0,1 ml prilokain dozu ile etkin olarak kontrol edilebilmektedir.

Anahtar Kelimeler: Ağrı, prilokain, prostat, periprostatik sinir blokajı, transrektal ultrason 


\section{Introduction}

Prostate cancer ( $\mathrm{PCa}$ ) is one of the most encountered cancers in men in worldwide (1). The transrectal ultrasound (TRUS) guided biopsy of prostate (PBX) is the gold standard method for the diagnosis of PCa (2). The pain and discomfort in patients under this procedure was reported by several studies $(3,4)$.

Different local anesthetic techniques for TRUS guided PBx procedure was described due to the pain and discomfort of the patients $(5,6,7,8,910)$. Intrarectal lubricant agents, periprostatic nerve blocks (PPNB), intraprostatic anesthesia, caudal or pudendal nerve blocks are some of the techniques described (11). Although it depends on the patient's characteristics and the urologist's experience, PPNB is the most effective and commonly used method in TRUS guided PBx (12). Although several researches were performed for various types and amounts of local anesthetic agents in PPNB $(5,6,7,8,9,10)$, the optimum type and doses of local anesthetic agent is still controversial.

There are some potential complications of PPNB during PBx. The local anesthetic agents have some side effects according to infiltration to circulation during PPNB. Nausea, anxiety and arrhythmias are some of these complications (11). Though, the needle punctures for injection and injected fluid have potential risks for bacterial contamination and urinary tract infection (11). Some authors have reported that the risk of sepsis did not increase with PPNB (13). The injection of local anesthetic agent is a painful procedure for the patient (14). Tüfek et al. (15) reported that the administration of low volume local anesthetic agent decreased the pain during both instillation of local anesthetic agent and biopsy, while there was no complication related to local anesthetic absorption and the procedure.

The reduction of pain during TRUS guided PBx with the lowest complication risk of PPNB is important for urologists. In the present study, we aimed to investigate the optimum dose of prilocaine in PPNB during TRUS guided PBX.

\section{Materials and Methods}

We retrospectively evaluated the medical records of patients with TRUS guided PBx due to elevated serum prostate specific antigen (PSA) levels and/or presence of abnormalities in digital rectal examination between years 2011 and 2013 in our center. This study was approved by our University Institutional Review Board (Project No: KA 13/40).

The inclusion criteria of patients in this study were;

- Patients with the first TRUS guided PBx due to elevated serum PSA level and/or presence of abnormalities in digital rectal examination.

- Patients with 12 core TRUS guided PBx.

- The administration of $5 \mathrm{~mL}$ prilocaine as the only local anesthetic method during TRUS guided PBx (this method is routinely used in our clinic).

On the other hand, the exclusion criteria of patients were the presence of bleeding diathesis, urinary tract infection, anticoagulant therapy, history of allergy to local anesthetic agents, re-biopsy, different doses or types of local anesthetic agents as lidocaine or bupivacaine and additional local anesthesia during PBx. We retrospectively evaluated the medical records of 165 patients and according to inclusion and exclusion criteria,
83 patients were included in the study. Antibiotic prophylaxis with $500 \mathrm{mg}$ ciprofloxacin were initiated the night before the $\mathrm{PBx}$ and continued twice daily for three days after the procedure in all patients. None of the patients was administrated fleet enema or oral analgesics before the procedure.

The Technique of Periprostatic Nerve Blocks During Transrectal Ultrasound Guided Prostate Biopsy and Evaluation of Pain All procedures were performed by the same urologists (M.K., U.G.) in an outpatient setting. The patient was placed in left lateral decubitus position in all ultrasound evolutions, local anesthesia administration and PBx sections. A Logiq C2 ultrasound device with a transrectal probe (GE Healthcare, Milwaukee, Wisconsin, USA) was used to evaluate the prostate and the local anesthetic agent was injected with a 22 gauge, $20 \mathrm{~cm}$ Chiba aspiration biopsy needle (Geotek Medical Cooporation, Ankara, Turkey) in all patients. Five $\mathrm{mL} 2 \%$ prilocaine (2.5 $\mathrm{mL}$ to each side) was injected just lateral to the junction between the prostate base and seminal vesicle on each side for PPNB. The prostate was examined in transverse and sagittal planes after prilocaine infiltration. Prostatic sizes were evaluated separately as Size 1 (anterior-posterior on the axial plane), Size 2 (transversal), and Size 3 (cranial-caudal on the sagittal plane) in all patients. The ellipsoid formula (Size $1 \times$ Size $2 \times$ Size $3 \times 0.52$ ) was used in the calculation of prostate volume. Five minutes after prilocaine injection, the PBx was performed in transverse plane using a 12 cores technique (conventional sextant biopsies+6 laterally targeted biopsies in apex, midzone and base of prostate bilaterally) with 18 gauge, $25 \mathrm{~cm}$ maxicore automatic biopsy gun needle using a biopsy gun (Geotek Medical Cooporation, Ankara, Turkey). Following the procedure, all patients were evaluated for the level of their pain during the biopsies with a visual analog scale (VAS) from 0 (no pain) to 10 (worst pain) points.

Although all patients were injected $5 \mathrm{~mL} 2 \%$ prilocaine in PPNB, the dosage of $2 \%$ prilocaine per $1 \mathrm{~mL}$ prostate volume was calculated for each patient $(5 \mathrm{~mL} 2 \%$ prilocaine/prostate volume of patient). We evaluated the correlation between VAS of patients during PBx and patient's characteristics, prostatic volumes, the prostatic sizes and the dosage of $2 \%$ prilocaine per $1 \mathrm{~mL}$ prostate. Also we evaluated the VAS-2\% prilocaine dose response graphic.

\section{Statistical Analysis}

The data were presented as mean \pm standard deviation. SPSS 16.0 for Windows (SPSS Inc., Chicago, Illinois, USA) software was used for statistical analysis. The power analysis of the study was calculated by a statistician before the evaluation of patients' medical records. It was found that a case volume with 83 patients had a $85 \%$ power analysis. The mean values of patients data was evaluated with descriptive statistical tests. The Spearman's correlation test was used to evaluate the correlation between VAS and 2\% prilocaine dosage, prostate sizes and prostate volume. We also used the cubic regression test for the relationship between VAS and $2 \%$ prilocaine dosages. The values of $p<0.05$ were considered as statistically significant.

\section{Results}

The medical records of the patients were retrospectively evaluated. The characteristics of patients are presented in Table 
1. The pathological findings of patients in $\mathrm{PBx}$ were benign prostatic hyperplasia in 59 (71.1\%) patients, PCa in $18(21.7 \%)$ patients, high grade prostatic intraepithelial neoplasia in one (1.2\%) patient and atypical small acinar proliferation in 5 (6\%) patients. According to these results, the main pathological diagnosis was benign prostatic hyperplasia in our patients. PCa was diagnosed in $18(21.7 \%)$ patients. The complications of procedure were observed only in $3(3.6 \%)$ patients. One (1.2\%) patient with fever and urinary tract infection was hospitalized one day after the procedure. One (1.2\%) patient had a vasovagal syncope and another (1.2\%) had transient arrhythmia during the procedure. These two biopsies in these patients were completed after the conservative therapy.

We evaluated the correlation between the VAS during PBx and other variables as prilocaine dosage per $1 \mathrm{~mL}$ prostatic tissue and prostatic sizes (Table 2). According to these results, VAS of the patients were significantly positive moderate correlated with prostatic volume, Size 1 and 3 . on the other hand, there was a significantly negative moderate correlation between VAS and prilocaine dose per $1 \mathrm{~mL}$ prostate $(r=-0.402, p<0.01)$.

Our results showed that the most powerful correlation was between VAS of the patients and prilocaine dosage per $1 \mathrm{~mL}$ prostatic tissue. The graphic of the relationship between VAS and prilocaine dosage is presented in Figure 1. The formula of the graphic was found to be below according to cubic regression test. The dose of $0.1 \mathrm{~mL}$ prilocaine infiltration per $1 \mathrm{~mL}$ prostatic tissue in PPNB was the maximum dose that caused a mild and under annoying pain $(\mathrm{VAS}<2)$ in patients with TRUS guided 12 core $\mathrm{PBx}$ according to this formula (Figure 1).

Table 1. The demographic characteristics and prostate sizes of patients

\begin{tabular}{|l|l|}
\hline Parameters & Mean \pm SD \\
\hline Age (year) & $64.8 \pm 7.9$ \\
\hline PSA $(\mathrm{ng} / \mathrm{mL})$ & $15.1 \pm 18.1$ \\
\hline Size $1(\mathrm{~mm})$ & $41.5 \pm 10.5$ \\
\hline Size $2(\mathrm{~mm})$ & $57 \pm 7.9$ \\
\hline Size $3(\mathrm{~mm})$ & $53.6 \pm 10.3$ \\
\hline Prostate volume $(\mathrm{ml})$ & $72.2 \pm 47.1$ \\
\hline VAS & $2.3 \pm 1.9$ \\
\hline PSA: Prostate specific antigen, VAS: Visual analog scale, SD: Standard deviation \\
\hline
\end{tabular}

Table 2. The Spearman's Correlation tables according to visual analog scale score

\begin{tabular}{|l|l|l|}
\hline Parameters & r value & p value \\
\hline Age & -0.019 & 0.86 \\
\hline PSA & +0.187 & 0.09 \\
\hline Prilocaine dosage & -0.402 & $<0.01$ \\
\hline Size 1 & +0.389 & $<0.01$ \\
\hline Size 2 & +0.232 & 0.03 \\
\hline Size 3 & +0.328 & $<0.01$ \\
\hline Prostate volume & +0.303 & $<0.01$ \\
\hline PSA: Prostate specific antigen & \\
\hline
\end{tabular}

The formula of VAS-Prilocaine dosage curve: VAS $=4.545$ $(36.847 \times$ dosage $)+\left(122.14 x_{\text {dosage }}{ }^{2}\right)-\left(139.111\right.$ xdosage $\left.^{3}\right)$

\section{Discussion}

TRUS guided PBx is the main method in the diagnosis of $\mathrm{PCa}$ (2). A significant pain was reported by investigators in $30 \%$ of the patients $(3,4)$. Pain and discomfort during PBx depend on neuroanatomy of prostate and anal canal. Prostate parenchyma and prostate capsule are more sensitive to pain in comparison with rectal mucosa. The perforation of prostate capsule with biopsy needle mainly generates the pain that is transmitted through the neurovascular bundles. The nerves with sensorial innervations of prostate capsule and stroma pass through the posterolateral border of the prostate capsule at prostatic base $(11,16,17,18)$. Local anesthesia is widely used to reduce the pain and discomfort of patients during TRUS guided PBx $(11,19)$.

There are various types of local anesthesia during PBx such as intrarectal local anesthetic gel, PPNB, intraprostatic anesthesia, pelvic plexus blockade $(11,19)$. The usage of PPNB in the control of pain during PBx was first described by Nash et al. (16). PPNB is the infiltration of local anesthetic agent around the neurovascular bundle of prostate. Several meta-analyses have reported that PPNB is the best method to control the pain during TRUS guided PBx $(11,19)$. Various anesthetic agents as lidocaine, bupivacaine and mepivacaine have been used in PPNB. The most frequently used agent is lidocain with long duration of action and low incidence of side effects (11). Although Tiong et al. (19) reported that the complications according to biopsy procedure or local anesthetic agents did not increase in patients with PPNB in their meta-analysis, it is well known that the local anesthetic agents have several side effects including arrhythmias, hypotension and anxiety (11). Though it was reported that the incidence of fever, urinary tract infection and hospitalization after TRUS guided $\mathrm{PBx}$ are higher in patients with PPNB, it was known that these complications were also common in patients without PPNB (11). On the other hand, Gan et al. (13) reported that PPNB during TRUS guided PBx did not increase the risk of sepsis. Song et al. (20) also reported the incidence of vasovagal syncope was $1 \%$. Turgut et al. (21) reported that systemic lidocaine toxicity had been seen in $2 \%$ of patients with PPNB. In this study, we

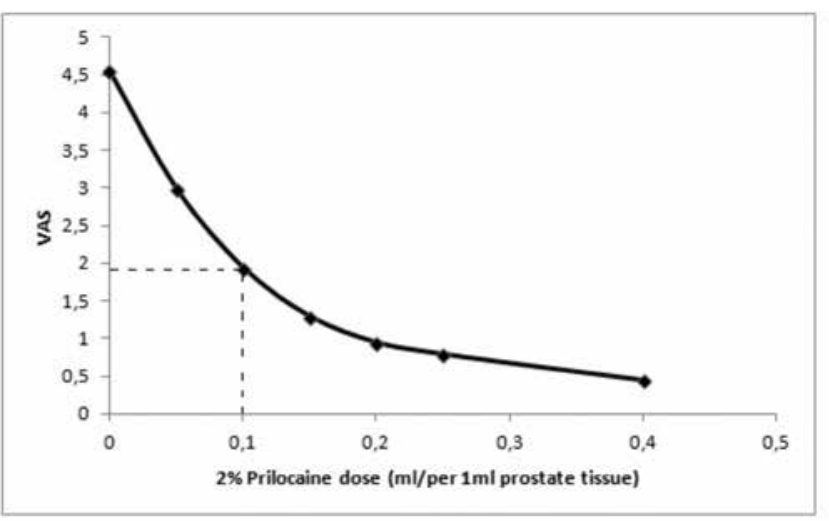

Figure 1. The graphic of visual analog scale scores and prilocaine dosage according to cubic regression test

VAS: Visual analog scale 
observed the vasovagal syncope in one (1.2\%) patient and transient arrhythmia in one (1.2\%) patient. It was needed to hospitalize one (1.2\%) patient due to fever and urinary infection in our study.

There are several studies with different type, concentration or dosage of local anesthetic agents in PPNB during TRUS guided PBx $(10,15,22,23,24,25)$. The technique of PPNB was also different in recent studies $(8,22,23,26)$. The most frequently used agent in PPNB was lidocaine with 1-2\% concentrations $(11,19,22,23)$. The widely used applications of lidocaine were 5 or $10 \mathrm{~mL}$ in several studies $(6,8,26)$. Although it was reported that patients had lower pain during $\mathrm{PBx}$ with high volume of local anesthetics in PPNB, the high concentration of local anesthetics in low volumes had better control of pain in PBx $(9,15,27)$. Bupivacaine, ropivacaine and prilocaine are the less frequently used agents in PPNB $(5,10)$. The bilateral angel between the prostate base and seminal vesicle is the most common injection site in PPNB (11). In this study, $5 \mathrm{~mL} 2 \%$ prilocaine $(2,5 \mathrm{~mL}$ per each side) was used in PPNB and injected the local anesthetic to the angel between the prostate base and seminal vesicle bilaterally.

In a recent review, Loeb et al. (28) presented the prostate volume as another predictor for pain during PBx. Some investigators reported that the prostate volume was not an important risk factor for pain associated with PBx (29). Bastide et al. (29) evaluated the risk factors of pain during PBx in patients without any anesthetic method and reported that the only risk factor for pain was the initial localization of PBx. On the other hand, Giannarini et al. (6) compared the efficiency of combination perianal-intrarectal lidocaine-prilocaine cream and PPNB with the two modalities alone during PBx. They reported that the combination of both anesthetic methods had better pain control during $\mathrm{PBx}$ and this effect was higher in patients with larger prostate volume. Patients with larger prostate volume needed more anesthetics during PBx (6). Additionally, Yun et al. (30) showed that patients with prostate volume larger than $40 \mathrm{~mL}$ had more pain during and after TRUS guided $\mathrm{PBx}$ in comparison with patients with smaller prostate. Eight $\mathrm{mL}$ of $1 \%$ lidocaine was administered to all patients at both basolateral region of prostate for PPNB in their study (30). In this study, we did not evaluate the patients by dividing into groups according to their prostate volumes. We evaluated the relationship between the VAS of patients during PBx and the sizes of prostate. Prostate volume and the prostatic sizes were positively correlated with VAS of the patients. We found that the anatomical structure of prostate had an impact on the efficiency of PPNB. Anterior-posterior and cranial-caudal sizes of prostate had stronger relationships with VAS in comparison of prostate volume. The increased sizes of prostate might affect the infiltration anesthesia of periprostatic nerve negatively in these patients. It was found that the dosage of prilocaine per 1 $\mathrm{mL}$ prostatic tissue was negatively correlated with VAS and the optimum dosage for PBx procedure was $0.1 \mathrm{~mL}$ prilocaine per $1 \mathrm{~mL}$ prostatic tissue in PPNB. The VAS of the patients with this optimum dosage of prilocaine was under annoying pain (VAS $<2$ ) according to dose-response curve in our study.

To thwe best of our knowledge, this study is the first one to calculate the optimum dosage of local anesthetic agent in PPNB according to prostatic volume. We found that $0.1 \mathrm{~mL}$ prilocaine per $1 \mathrm{~mL}$ prostatic tissue in PPNB made the procedure less painful for patients with 12 cores PBx. The optimum dosage for anesthetic agents is important due to avoid the possible side effects of agents and puncture of needle. This study has some limitations according to its retrospectively designed nature. The main limitation of the study was the absence of the VAS of patients during PPNB and post PBx. We only evaluated the VAS of patients during PBx. Another limitation was the usage of single kind of local anesthetic agent prilocaine in our study. The present study showed the relationship between the prostatic volume and the pain during PBx. The importance of this study was the calculation of an optimum dosage of local anesthetic agent in PPNB according to the prostatic volume. We found that the pain during $\mathrm{PBx}$ was negatively correlated with the dosage of prilocaine per $1 \mathrm{~mL}$ prostatic tissue and positively correlated with prostatic sizes (especially anteriorposterior and cranial-caudal sizes) and volume. The changes in anatomical structure of prostate have an impact on infiltration anesthesia of local anesthetic agents in PPNB. The optimum dosage of prilocaine was $0.1 \mathrm{~mL}$ prilocaine per $1 \mathrm{~mL}$ prostatic tissue in PPNB for patients with 12 cores PBx. Unfortunately; prospectively designed studies with high caseloads are needed to find the optimum dosages for all local anesthetic agents in PPNB during TRUS guided PBX.

\section{Ethics}

Ethics Committee Approval: This study was approved by Başkent University Institutional Review Board (Project No: KA 13/40), Informed Consent: This study was retrospectively designed. All patients have informed consist for transrectal ultrasound guided prostate biopsy and periprostatic nevre blockade.

Peer-review: Internal peer-reviewed.

\section{Authorship Contributions}

Surgical and Medical Practices: Umut Gönülalan, Murat Koşan, Concept: Umut Gönülalan, Murat Koşan, Design: Umut Gönülalan, Murat Koşan, Tufan Çiçek, Bülent Öztürk, Data Collection or Processing: Umut Gönülalan, Murat Koşan, Enis Kervancıoğlu, Tufan Çiçek, Analysis or Interpretation: Umut Gönülalan, Murat Koşan, Enis Kervancıoğlu, Tufan Çiçek, Hakan Özkardeş, Literature Search: Umut Gönülalan, Writing: Umut Gönülalan, Murat Koşan.

Conflict of Interest: Authors have declared no conflict of interest. Financial Disclosure: This study have no financial support form a person or institution.

\section{References}

1. Parkin DM, Bray F, Ferlay J, Pisani P. Global cancer statistics, 2002. CA Cancer J Clin 2005;55:74-108.

2. Ramey CR, Halpern EJ, Gomella LJ. Ultrasonography and biopsy of the prostate: Prostate biopsy techniques and outcomes. In: Wein AJ, Partin AW, Novick AC, Kavoussi LR, Peters CA, editors. CampbellWalsh Urology. 9th ed, vol 3. Philadelphia: Saunders; 2006. s. 2887-2892.

3. Clements R, Aideyan OU, Griffiths G], Peeling WB. Side effects and patient acceptability of transrectal biopsy of the prostate. Clin Radiol 1993;47:125-126.

4. Collins GN, Lloyd SN, Hehir M, McKelvie GB. Multiple transrectal ultrasound-guided prostatic biopsies-true morbidity and patient acceptance. Br J Urol 1993;71:460-463.

5. Yurdakul T, Taspinar B, Kilic O, et al. Topical and long acting local 
anesthetic for prostate biopsy: A prospective randomized placebocontrolled study. Urol Int 2009;83:151-154.

6. Giannarini G, Autorino R, Valent F, et al. Combination of perianalintrarectal lidocaine-prilocaine cream and periprostatic nerve block for pain control during transrectal ultrasound guided prostate biopsy: A randomized controlled trial. J Urol 2009;181:585-591.

7. Cantiello $F$, Imperatore $V$, lannuzzo $M$, et al. Periprostatic nerve block (PNB) alone vs PNB combined with an anaesthetic-myorelaxant agent cream for prostate biopsy: A prospective, randomized doublearm study. BJU Int 2009;103:1195-1198.

8. Akan H, Yildiz O, Dalva I, Yucesoy C. Comparison of two periprostatic nerve blockade techniques for transrectal ultrasound guided prostate biopsy: Bilateral basal injection and single apical injection. Urology 2009;73:23-26.

9. Ozden E, Yaman $O$, Göğüs $C$, et al. The optimum doses of and injection locations for periprostatic nerve blockade for transrectal ultrasound guided biopsy of the prostate: A prospective, randomized, placebo controlled study. J Urol 2003;170:2319-2322.

10. Başar H, Başar MM, Ozcan S, et al. Local anesthesia in transrectal ultrasound-guided prostate biopsy: EMLA cream as a new alternative technique. Scand J Urol Nephrol 2005;39:130-134.

11. Maccagnano, C, Scattoni V, Roscigno $M$, et al. Anaesthesia in transrectal prostate biopsy: Which is the most effective technique? Urol Int 2011;87:1-13.

12. Autorino R, De Sio M, Di Lorenzo G, et al. How to decrease pain during transrectal ultrasound guided prostate biopsy: A look at the literature. J Urol 2005;174:2091-2097.

13. Gan VH, Kuo TL, Lee LS, et al. Does periprostatic block increase the transrectal ultrasound (TRUS) biopsy sepsis rate in men with elevated PSA? Ann Acad Med Singapore 2013;42:168-172.

14. Ingber MS, Ibrahim I, Turzewski $C$, et al. Does periprostatic block reduce pain during transrectal prostate biopsy? A randomized, placebo-controlled, double-blinded study. Int Urol Nephrol 2010;42:23-27.

15. Tüfek I, Akpinar $H, A$ tug $F$, et al. The impact of local anesthetic volume and concentration on pain during prostate biopsy: A prospective randomized trial. J Endourol 2012;26:174-177.

16. Nash PA, Bruce JE, Indudhara R, Shinohara K. Transrectal ultrasound guided prostatic nerve blockade eases systematic needle biopsy of the prostate. J Urol 1996;155:607-609.

17. Shinohara K. Pain: Easing the pain: Local anesthesia for prostate biopsy. Nat Rev Urol 2009;6:360-361.
18. Hollabaugh RS Jr, Dmochowski RR, Steiner MS. Neuroanantomy of the male rhabdosphincter. Urology 1997;49:426-434.

19. Tiong HY, Liew LC, Samuel M, et al. A meta-analysis of local anesthesia for transrectal ultrasound-guided biopsy of the prostate. Prostate Cancer Prostatic Dis 2007; 10:127-136.

20. Song SH, Kim JK, Song K, et al. Effectiveness of local anesthesia techniques in patients undergoing transrectal ultrasound-guided prostate biopsy: A prospective randomized study. Int J Urol 2006;13:707-710.

21. Turgut AT, Olçücüoğlu $E$, Kosar $P$, et al. Complications and limitations related to periprostatic local anesthesia before TRUS-guided prostate biopsy. J Clin Ultrasound 2008;36:67-71.

22. Addla SK, Adeyoju AA, Wemyss-Holden GD, Neilson D. Local anaesthetic for transrectal ultrasound-guided prostate biopsy: A prospective, randomized, double blind, placebo controlled study. Eur Urol 2003;43:441-443.

23. Obek C, Ozkan B, Tunc B, et al. Comparison of 3 different methods of anesthesia before transrectal prostate biopsy; a prospective randomized trial. J Urol 2004;172:502-505.

24. Von Knobloch R, Weber J, Varga Z, et al. Bilateral fine-needle administered local anesthetic nerve block for pain control during TRUS-guided multi-core prostate biopsy: A prospective randomised trial. Eur Urol 2002;41:508-514.

25. Mallick S, Humbert M, Braud F, et al. Local anesthesia before transrectal ultrasound guided prostate biopsy: Comparison of 2 methods in a prospective, randomized clinical trial. J Urol 2004;171:730-733.

26. Bingqian L, Peihuan L, Yudong W, et al. Intraprostatic local anesthesia with periprostatic nerve block for transrectal ultrasound guided prostate biopsy. J Urol 2009;182:479-483.

27. Berger AP, Frauscher F, Halpern EJ, et al. Periprostatic administration of local anesthesia during transrectal ultrasound-guided biopsy of the prostate: A randomized, double blind, placebo-controlled study. Urology 2003;61:585-588.

28. Loeb S, Vellekoop A, Ahmed HU, et al. Systematic review of complications of prostate biopsy. Eur Urol 2013;64:876-892.

29. Bastide C, Lechevallier E, Eghazarian C, et al. Tolerance of pain during transrectal ultrasound-guided biopsy of the prostate: Risk factors. Prostate Cancer Prostatic Dis 2003;6:239-241.

30. Yun TJ, Lee HJ, Kim SH, et al. Prospective analysis on the relation between pain and prostate volume during transrectal prostate biopsy. Korean J Radiol 2007;8:231-235. 